\title{
Effect of Integrated Nutrient Management on Yield, Yield Attributes and Economics of Broccoli
}

\author{
S.K. Dash ${ }^{1}$, G.S. Sahu ${ }^{1}$, S. Das ${ }^{1}$, S. Sarkar ${ }^{1}$ and M. Pathak ${ }^{2}$
}

${ }^{1}$ Directorate of Research, AICRP on Vegetable Crops, OUAT, Bhubaneswar, Odisha, India

${ }^{2}$ Department of Vegetable Science, CA, OUAT, Bhubaneswar, Odisha, India

*Corresponding author

\section{A B S T R A C T}

\section{Keywords}

Integrated Nutrient

Management,

Economiics of

Broccoli,

Vermicompost

Article Info

Accepted:

18 May 2019

Available Online:

10 June 2019
Present investigation was undertaken to study the effect of INM on growth and yield of broccoli cv. Shayali. For this, a field experiment was carried out in Randomized Block Design with three replications. The experiment was conducted at the All India Crop Research Project, during Rabi season of 2014-15. For the experiment, Nine treatment combinations viz. 100\% RDF $\left(\mathrm{T}_{1}\right)$, FYM @ 20 tonnes /ha $\left(\mathrm{T}_{2}\right), 50 \%$ RDF + FYM @ 10 tonnes/ha $\left(\mathrm{T}_{3}\right)$, Neem cake@5q/ha $\left(\mathrm{T}_{4}\right), 50 \% \mathrm{RDF}+$ Neem cake @ 2.5q/ha $\left(\mathrm{T}_{5}\right)$, Vermicompost @ 5 t/ha $\left(\mathrm{T}_{6}\right), 50 \%$ RDF+ Vermicompost @2.5t/ha $\left(\mathrm{T}_{7}\right)$, Poultry manure@5t/ha $\left(\mathrm{T}_{8}\right), 50 \% \mathrm{RDF}+$ Poultry manure @ 2.5t/ha $\left(\mathrm{T}_{9}\right)$. Sayali variety of broccoli was transplanted at a spacing of $50 \mathrm{~cm} \times 45 \mathrm{~cm}$. Results revealed that the treatment $\mathrm{T}_{7}(50 \%$ RDF + Vermicompost @ 2.5t/ha) recorded maximum values for recorded highest head length $(14.67 \mathrm{~cm})$, head width $(13.37 \mathrm{~cm})$, gross head weight $(348.22 \mathrm{~g})$, net head weight $(298.85 \mathrm{~g})$, marketable yield $\left(13.25 \mathrm{~kg} \mathrm{plot}^{-1}\right)$ marketable yield $(163.60 \mathrm{q} / \mathrm{ha})$, and benefit: cost ratio (3.93) followed by treatment $\mathrm{T}_{9}(50 \% \mathrm{NPK}+$ poultry manure) and $100 \% \mathrm{RDF}$ $\left(\mathrm{T}_{1}\right)$.

\section{Introduction}

Broccoli (Brassica oleracea L. var. italica Plenck $2 \mathrm{n}=\mathrm{x}=18$ ), which is originated from the Mediterranean region commonly known as Hari gobhi in Hindi and a member of Cole group, belongs to the family Brassicaceae or Cruciferae (mustard family). Broccoli is an Italian vegetable which is cultivated in Italy in ancient roman times. Commercial cultivation of broccoli was started around 1923 (Decoteau, 2000). Watt (1983) reported that broccoli is more nutritious than any other
Cole crops such as cabbage, cauliflower and kohlrabi. On the other hand, broccoli is environmentally better adapted than cauliflower, and reported to with stand comparatively at higher temperature than cauliflower (Rashid, 1976). Brassica vegetables possess both antioxidant and anticarcinogenic properties (Cartea et al., 2008) and it is well known that dietary intake of food containing antioxidants provides effective support for the body's defensive systems and may prevent some diseases (Mc Carty, 2008) Broccoli is one of the most 
nutritious Cole crops and contains vitamin A (130 times and 22 times higher than cauliflower and cabbage, respectively), thiamin, riboflavin, niacin, vitamin $\mathrm{C}$ and minerals like $\mathrm{Ca}, \mathrm{P}, \mathrm{K}$ and $\mathrm{Fe}$ ( Kumar et al., 2011). Broccoli contains indole-3-carbinol which helps to fight breast and lung cancer (Anon. 2006). It is used as curries, soups and pickles and also eaten as a salad and cooked as a single or mixed vegetable with potato (Thamburaj and Singh, 2001). Broccoli is a cool-loving crop and very sensitive to high temperature which cause the heads to be distorted, making it a high-risk crop.

Integrated nutrient management (INM) consists of improvement and maintenance of soil fertility for sustainable crop productivity through optimization of all available organic, inorganic and biotic resources in an integrated manner, appropriate to each cropping system and farming situations with its ecological, social and economic ramifications. Recent energy crisis and consequent price hike of chemical fertilizers due to withdrawal of relevant subsidies coupled with low purchasing power of farming community have generated renewed interest in organic recycling throughout the world for sustainable crop production (Agarwal, 2000).

There is an urgent need to adopt an integrated nutrient supply and management system for promoting efficient and balanced use of plant nutrients. While the main emphasis was given on increasing the proper and balanced used of mineral fertilizers, the role of organic manure, biofertilizers, green manuring and recycling of organic wastes should be considered supplementary and not substitutable.

Being a newly introduced crop of Odisha, there was an urgent need for standardization of integrated nutrient management packages having locally available organic sources integrated with chemical fertilizers. Keeping this in view, the research was carried out with the objectives to study the effect of integrated application of inorganic and organic manures on yield and yield attributes of broccoli.

\section{Materials and Methods}

The present investigation was undertaken to ascertain the effect of integrated management of nitrogen, phosphorus and potassic fertilizers through organic manures in sprouting broccoli during the period of December 2014 to March 2016 in three consecutive Rabi seasons. The broccoli variety used in this experiment is Shayali, which is an early maturity variety, which takes around 70 days for $1^{\text {st }}$ harvesting from transplanting, with the plant height being around $50 \mathrm{~cm}$ and average head weight being $250 \mathrm{gm}$. The experiment was conducted in RBD design with 3 replications. The experiment was conducted in plots of size $3 \mathrm{~m}$ x $2.7 \mathrm{~m}$ with a spacing of $50 \mathrm{~cm}$ in between rows and $45 \mathrm{~cm}$ in between plants. Fertilizers were provided at a dose of $200 \mathrm{~kg}$ nitrogen, $50 \mathrm{~kg}$ phosphorus and $100 \mathrm{~kg}$ potash per hectare. The sources of fertilizers (both organic and inorganic) used were the basis of formation of different treatment combinations. The details of the treatment are $\mathrm{T}_{1}$ : Full dose of NPK through chemical fertilizer, $\mathrm{T}_{2}$ : FYM@ 20t/ha, $\mathrm{T}_{3}$ : FYM @ 10t/ha + half NPK through fertilizer, $\mathrm{T}_{4}$ : Neem Cake@5q/ha, T5: Neem Cake @ $2.5 \mathrm{q} / \mathrm{ha}+$ half NPK through fertilizer, $\mathrm{T}_{6}$ : Vermicompost @ 5t/ha, T 7 : Vermicompost @ 2.5t/ha + half NPK through fertilizer, $\mathrm{T}_{8}$ : Poultry manure @ 5t/ha, $\mathrm{T}_{9}$ : Poultry manure @ 2.5t/ha + half NPK through fertilizer. The observations were taken on different yield and yield attributing characters like gross head weight, net head weight, yield etc. The B: C ratio was calculated taking into considerations of the costs incurred and income generated. The statistical formulas were used for compilation of data and drawing of conclusion. 


\section{Results and Discussion}

Several factors have been found to influence growth and yield of high value crops like vegetables, which ensure high and quick returns per unit area and time. It is an established fact that continuous sole and imbalanced use of chemical fertilizers leads to deterioration of soil health and ecological balance in conjunction with decrease in nutrient uptake efficiency of the applied nutrients. Although chemical fertilizers contribute a lot in fulfilling the nutrient requirement of sprouting broccoli, which is an exhaustive crop, but their regular, excessive and unbalanced use may lead to deterioration of physical and chemical properties of the soil and ultimately poor crop yields. Consequently, there is stagnation or plateau in crop yield and this poses challenge to environment and food safety.

It was observed that the head length and head width were markedly influenced by different treatments. The data shown in table 1 revealed that the length of broccoli head is significantly at par in the treatment containing 2.5 tonnes/ha of vermicompost $+50 \% \mathrm{RDF}$ was on par with all other treatments except $\mathrm{T}_{4}$ and $\mathrm{T}_{6}$. The maximum head width was observed in treatment $\mathrm{T}_{7}(13.37 \mathrm{~cm})$ followed by $\mathrm{T}_{9}(13.31 \mathrm{~cm}) \& \mathrm{~T}_{5}(13.18 \mathrm{~cm})$. The lowest head diameter was observed in $\mathrm{T}_{4}$ where neem cake @ 5q/ha was applied.

The data regarding effect of integrated nutrient management on curd/head weight is presented in Table 1. A perusal of detailed data analyzed indicated that weight of head per plant showed significant variation among the treatments. The data revealed that the lowest gross head weight of $280.57 \mathrm{~g}$ in broccoli was found in $\mathrm{T}_{4}$ plots, which were fertilized with neem cake only @ 5q/ha. It was found that in broccoli maximum gross head weight was obtained in treatment $T_{1}(367.56$ g) with (Full dose of NPK through fertilizers) which was on par with $T_{3}, T_{5}, T_{7}$ and $T_{9}$. The lowest net head weight of $220.30 \mathrm{~g}$ in broccoli was found in $\mathrm{T}_{4}$ plots again and maximum net head weight was obtained in treatment $\mathrm{T}_{7}$ (298.85 g) with (Vermicompost @ 2.5 T/ha + $50 \%$ NPK through fertilizers) which was on par with $\mathrm{T}_{1}(279.52 \mathrm{~g})$ with (Full dose of NPK through chemical fertilizer), $\mathrm{T}_{3}(269.43 \mathrm{~g})$ with (FYM @ 10t/ha+1/2 NPK through fertilizer), $\mathrm{T}_{5}(267.32 \mathrm{~g})$ with (Neem Cake @ $2.5 \mathrm{q} / \mathrm{ha}+1 / 2$ NPK through fertilizer) and $\mathrm{T}_{9}$ $(277.14$ g) (Poultry manure @ 2.5t/ha+1/2 NPK through fertilizer).The increase in net head weight might be due to the more photosynthesis from a larger area of the leaves and the translocation of photosynthates to the sink which is ultimately the head. The increase in the net head weight at this level might also be due to the increase in the leaf weight and also due to higher values of head length and head width cited by Sharma et al., (2008).

It was clearly observed that a wide variation in yield per plot and per hectare can be obtained by altering the different fertilizer levels among the treatments. The head yield per plot and per hectare showed significant variations among all the treatments. The data in the clearly signifies that a wide variation in total head yield per plot can be obtained by altering the levels of $\mathrm{N}, \mathrm{P}$ and $\mathrm{K}$ among the treatments. Highest yield per plot $(13.25 \mathrm{~kg})$ was obtained from $\mathrm{T}_{7}$ (Vermicompost @2.5 $\mathrm{T} / \mathrm{ha}+50 \%$ NPK through fertilizers) followed by $12.53 \mathrm{~kg}$ in $\mathrm{T}_{1}, 12.24 \mathrm{~kg}$ in $\mathrm{T}_{9}$ and 11.70 $\mathrm{kg}$ in $\mathrm{T}_{3}$, which were on par with each other. Lowest yield per plot $(7.49 \mathrm{~kg})$ was recorded in plot T4. It was found that the various doses of nutrient produced significant variation in total head yield per plot. Highest head yield (163.60 t/ha) per hectare was recorded in $\mathrm{T}_{7}$ followed by $154.74 \mathrm{t} / \mathrm{ha}$ in $\mathrm{T}_{1}$. The beneficial role of farmyard manure and vermicompost in improving physical, chemical and biological 
properties of soil, which in turn, help in better nutrient absorption by plants, also resulted in higher values for yield contributing parameters. The study further revealed that various yield parameters (Table 1) have not been significantly influenced when organic manures are not applied (treatment $\mathrm{T}_{1}$ ), which signifies the role of organic manures in combination with inorganic fertilizers for enhancing yield parameters in sprouting broccoli. Similar results were reported by Bahadur et al., (2003) and Chaterjee et al., (2005) (Fig. 1).

Table.1 Effect of integrated nutrient management on yield and yield attributes of broccoli (Over a period of three years (2014-15 to 2016-17)

\begin{tabular}{|l|c|c|c|c|c|c|c|}
\hline Treatments & $\begin{array}{c}\text { Head } \\
\text { Length } \\
(\mathrm{cm})\end{array}$ & $\begin{array}{c}\text { Head } \\
\text { width } \\
(\mathrm{cm})\end{array}$ & $\begin{array}{c}\text { Gross } \\
\text { Head wt. } \\
(\mathrm{g})\end{array}$ & $\begin{array}{c}\text { Net } \\
\text { Head wt } \\
(\mathrm{g})\end{array}$ & $\begin{array}{c}\text { Net yield } \\
(\mathrm{Kg} / \mathrm{plot})\end{array}$ & $\begin{array}{c}\text { Net yield } \\
(\mathrm{q} / \mathrm{ha})\end{array}$ & $\begin{array}{c}\text { B:C } \\
\text { ratio }\end{array}$ \\
\hline $\begin{array}{l}\text { T1: Full dose of NPK through chemical } \\
\text { fertilizer }\end{array}$ & 14.60 & 12.65 & 367.56 & 279.52 & 12.53 & 154.74 & 4.30 \\
\hline T2: FYM @ 20t/ha & 13.93 & 13.17 & 309.41 & 239.61 & 8.42 & 103.94 & 2.50 \\
\hline $\begin{array}{l}\text { T3: FYM @ 10t/ha+1/2 NPK through } \\
\text { fertilizer }\end{array}$ & 14.03 & 13.12 & 350.01 & 269.43 & 11.70 & 144.38 & 3.73 \\
\hline T4: Neem Cake @5q/ha & 13.17 & 12.16 & 280.57 & 220.30 & 7.49 & 92.49 & 2.67 \\
\hline $\begin{array}{l}\text { 55: Neem Cake @ 2.5q/ha+1/2 NPK } \\
\text { through fertilizer }\end{array}$ & 14.02 & 13.18 & 323.63 & 267.32 & 11.01 & 135.92 & 3.90 \\
\hline T6: Vermicompost @5t/ha & 13.07 & 12.77 & 296.61 & 223.96 & 9.89 & 122.07 & 2.57 \\
\hline $\begin{array}{l}\text { T7: Vermicompost @2.5t/ha+1/2 NPK } \\
\text { through fertilizer }\end{array}$ & 14.67 & 13.37 & 348.22 & 298.85 & 13.25 & 163.60 & 3.93 \\
\hline T8: Poultry manure @ 5t/ha & 13.86 & 12.76 & 288.98 & 242.03 & 7.97 & 98.41 & 2.17 \\
\hline $\begin{array}{l}\text { T9: Poultry manure @2.5t/ha+1/2 NPK } \\
\text { through fertilizer }\end{array}$ & 14.33 & 13.31 & 352.52 & 277.14 & 12.24 & 151.16 & 3.70 \\
\hline CD @ 5\% & 1.45 & 1.41 & 57.49 & 43.34 & 1.80 & 22.27 & \\
\hline
\end{tabular}

Gross Head wt. - Head weight along with leaves and stalk; Net Head wt.- Head weight excluding leaves \& stalk

Fig.1

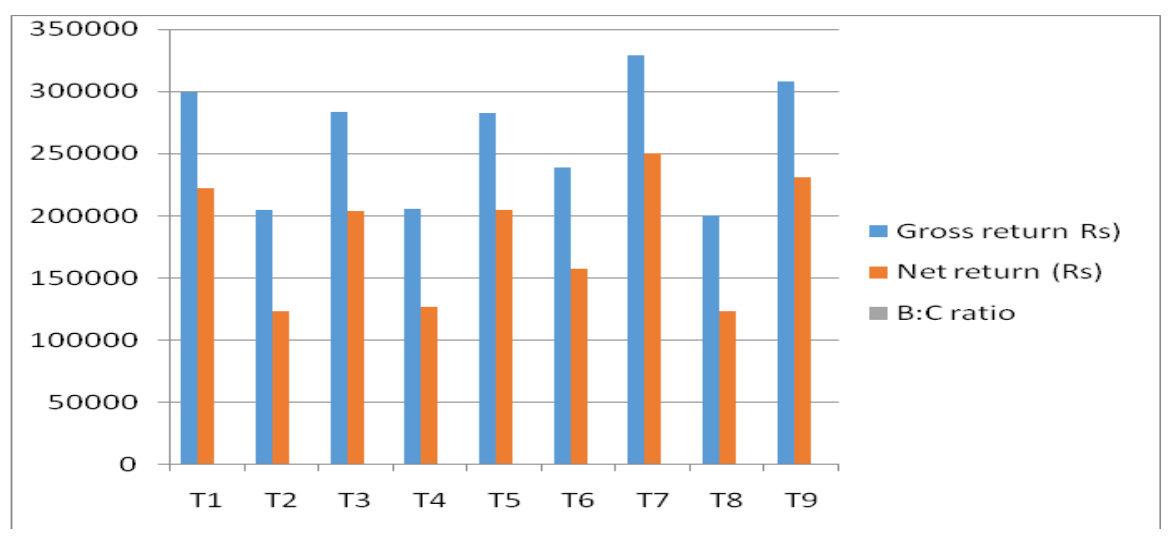

The B:C ratio of different treatment on sprouting broccoli with respect to gross and net returns per hectare and benefit cost ratio have been presented in Table 1 . The data presented depicted that highest benefit cost ratio (4.3) were obtained in $\mathrm{T}_{1}$ (Full dose of NPK through fertilizers), followed by treatment $\mathrm{T}_{7}$ (4.7). Lowest benefit cost ratio of 2.17 and 2.50 was 
recorded in treatment $\mathrm{T}_{8}$ (Poultry manure @ $5 \mathrm{t} / \mathrm{ha})$ and $\mathrm{T}_{2} \quad(20$ tonnes/ha of FYM $)$ respectively.

The present investigation on integrated application of inorganic fertilizers and vermicompost proved on par yield performance with $100 \%$ RDF whereas, treatments without inorganic manure resulted in significant reduction in growth and yield attributing parameters. Among all the treatments, application of $50 \% \mathrm{RDF} / \mathrm{ha}+2.5$ tonnes /ha vermicompost in sprouting broccoli was found to be the best for obtaining highest yield as well as good benefit cost ratio in Odisha condition.

\section{References}

Agarwal SK.2000. Role of integrated nutrient management using biological resources for sustainable agriculture, Microbes in Integrated Nutrient Management (Sep15 to Oct 12, 2002), A.A.R.E.M.C.C.S.H.A.U, Hissar.

Bahadur A, Singh J and Upadhaya AK. 2003. Effect of manures and bio fertilizers on growth, yield and quality attributes of broccoli (Brassica oleracea L. var. italica Plenck.), Vegetable Science, 30(2):192194.

Cartea, M. E. Pablo Velasco, S. O. and Guillermo Padilla, A. H. (2008). Seasonal variation in glucosinolate content in brassica oleracea crops grown in northwestern Spain. photochemistry, 69: 403-410.

Chaterjee B, Ghanti P, Thapa U and Tripathy P.
2005. Effect of organic nutrition in sprouting broccoli (Brassica oleracea L. var. italica Plenck.), Vegetable Science, 32(1): 51-54.

Decoteau, D. R. (2000). Vegetable crops. Upper rever company. New Jersey, U.S.A

Kumar, M. Das, B. Prasad, K. K. and Kumar, P. (2011). Effect of integrated nutrient management on quality of broccoli (Brassica oleraciavar var Italica) $\mathrm{cv}$. fiesta under Jharkhand conditions. The Asian Journal of Horticulture. 6: 388-392.

Mc carty and Mark, F. (2008). Scavenging of peroxynitrite derived radicals by flavonoids may support endothelial no syntheses activity, contributing to the vascular protection associated with high fruit and vegetable intakes. Medical hypotheses. 70: 170-181.

Rashid, M.M. (1976). Vegetable of Bangladesh (In Bengali). First edition. Bangla academy, dhaka. 283

Sharma A, Parmar DK, Kumar P, Singh Y and Sharma RP.2008. Azotobacter soil amendment integrated with cow manures reduces need for NPK fertilizers in Sprouting Broccoli, International Journal of Vegetable Science, 14(3): 273-285.

Thamburaj, S. and Singh, N. (2001). Vegetables, tuber crops and spices. Directorate of Information and Publications of Agriculture, ICAR, New Delhi. 137.

Watt, B. K. (1983). Nutritive Value of Fruits and Vegetables. USAID, Hand Book. An Avi Book Published by Van Nostrand Reinhold, New York. 369. 414.

\section{How to cite this article:}

Dash, S.K., G.S. Sahu, S. Das, S. Sarkar and Pathak, M. 2019. Effect of Integrated Nutrient Management on Yield, Yield Attributes and Economics of Broccoli. Int.J.Curr.Microbiol.App.Sci. 8(05): 3254-3258. doi: https://doi.org/10.20546/ijcmas.2019.806.387 